О. В. Гурко

\title{
РОЗПОВІДНІ РЕЧЕННЯ ЯК БАЗОВА МОДЕЛЬ У КОНТЕКСТІ ВІДНОШЕНЬ СТВЕРДЖЕННЯ / ЗАПЕРЕЧЕННЯ
}

Гурко О. В. Розповідні речення як базова модель у контексті відношень ствердження / заперечення.

Проаналізовано семантичну й комунікативну структури розповідного речення в аспекті відношень ствердження / заперечення, визначено його статус серед інших типів речення, з'ясовано, що розповідні речення $\epsilon$ базисними для вивчення стверджувального чи заперечного значення.

Ключові слова: ствердження, заперечення, розповідні речення, судження, базова модель, контекст, значення.

Гурко О. В. Повествовательные предложения как базовая модель в контексте отношений утверждения / отрицания.

В статье проанализированы семантическая и коммуникативная структуры повествовательного предложения в аспекте отношений утверждения / отрицания, определен его статус среди других типов предложения, выяснено, что повествовательные предложения являются базисными для изучения утвердительного или отрицательного значения.

Ключевые слова: утверждение, отрицание, повествовательные предложения, суждения, базовая модель, контекст, значение.

() О. В. Гурко, 2014. 
Hurko O. V. The narrative sentences as the basic model in the context of relations of affirmation / negation.

The semantic and communicative structures of narrative sentence in the aspect of affirmation / negation are analysed, its status among other types of sentence is determined. It is found out, that narrative sentences are a base for the study of affirmative or negative meaning.

Key words: affirmation, denial, narrative sentences, statement, basic model, context, meaning.

Сучасна лінгвістика характеризується тенденцією до розгляду синтаксичних явищ не лише в аспекті формальної структури, але й у плані вивчення їх функційно-семантичної організації на комунікативнопрагматичному рівні. Об'єктом нашого дослідження є розповідні речення української мови. Слід зазначити, що тривалий час цей тип речень зазвичай вивчали в порівнянні з питальними [2, с. 103]. Такі відомі мовознавці, як Д. М. Овсянико-Куликовський, О. М. Пєшковський уважають розповідні речення нульовою категорією й не уналежнюють їх до окремого типу речень. Проте П. С. Дудик стверджує, що розповідні речення становлять найуживаніший комунікативний різновид речень, $\epsilon$ досить різноманітними за своїм змістом i структурою, виражають відносно закінчену думку, нерідко найбільш нейтральні 3 погляду мовленнєвої емоційності [5, с. 75]. Аналіз семантичної та комунікативної структури розповідного речення в аспекті відношень ствердження / заперечення, визначення його статусу серед інших типів речення й зумовлює актуальність нашого дослідження.

Мета наукової розвідки - проаналізувати розповідні речення та показати, що вони є базисними в контексті відношень ствердження / заперечення.

В енциклопедії «Українська мова» автор статті А. П. Грищенко зазначає, що розповідне речення - це речення, комунікативне завдання якого полягає в констатації якого-небудь реального або ірреального факту, у повідомленні про нього в усній або писемній формі. За власне структурної та семантико-синтаксичної варіативності типовим для розповідного речення $\epsilon$ вираження предикатів первинними 3 функційного погляду формами дієслів дійсного й умовного способів та інфінітива. До найважливіших ознак розповідного речення належить т. 3. інтонація крапки, реалізована в мовленнєвій практиці у двох основних контурах руху основного тону - низхідному i висхіднонизхідному. Ці основні різновиди розповідної інтонації можуть зазнавати модифікаційних змін, зумовлюваних різним місцем логічного 
наголосу, варіюванням порядку слів, видозмінами лексичного наповнення речення [13, с. 584].

Для того, щоб глибше збагнути сутність розповідного (питального чи спонукального) речення як синтаксичної одиниці, потрібно вдатися до аналізу таких його диференційних ознак [5, с. 63]:

1) Предикативність, а також модальність розповідного речення, бо його зміст конкретно віднесений, пов'язаний з дійсністю, відбиває певні реалії. Наприклад, реченням Пора була весняна, ранішнє сонце так любо світило, не пекло, а гріло (8, с. 19) ми стверджуємо, повідомляємо про наявність конкретної весни, саме тієї, а не іншої, про їі буття в минулому.

Предикативність розповідного речення усвідомлюють у площині граматичних, частково й семантичних категорій - способу, часу, здебільшого й особи. Однією 3 ознак предикативності $\epsilon$ такий складник, як модальність речення, до якої зазвичай уналежнюють, поперше, протиставлення грамем дієслівного способу (дійсний, умовний і наказовий): Мої батьки щуасливі; Мої батьки були б щуасливі; Нехай батьки будуть щзасливими; по-друге, протиставлення речень за метою висловлювання - ствердження - питання - спонукання: У нас дружня родина; У нас дружня родина? Будьте дружньою родиною!; по-третє, протиставлення висловлювань за ознакою «ствердження заперечення»: Я прочитаю ц̧ю книжку - Я не прочитаю цую книжку, протиставлення речень окличних і неокличних: Щастя. - Щастя!

Проілюстровані вище приклади $\epsilon$ свідченням того, що факти об'єктивної дійсності мовець може тлумачити як дійсні (реальні) або як можливі (ірреальні) чи як бажані. Залежно від характеру віднесення висловленого до дійсності думку можуть сприймати як факт ствердження або заперечення, трактувати як певну можливість, необхідність, як факт спонукання чи вагання, невпевненості тощо. Відповідно розповідь може бути як стверджувальною, так і заперечною, а речення, якими іï виражають, - стверджувальними або заперечними. Обом реченням властива предикативність та модальність. М. В. Мірченко слушно зауважує, що категорія модальності та категорії ствердження / заперечення дуже тісно взаємодіють. Фактично підкатегорії можливості, потрібності, небажаності складають підкатегорії загального граматичного значення ствердження / заперечення [9, с. 86].

В. О. Горпинич серед засобів вираження суб’єктивної модальності, а отже, значення ствердження / заперечення виокремлює [4, с. 242]: (C) О. В. Гурко, 2014. 
1) специфічний лексико-граматичний клас слів, словосполучення й речення (можливо, очевидно, правда). Наприклад, лексема правда в поданому нижче реченні виражає впевненість мовця в тому, про що далі в реченні: Правда, досі Черниш уявляв собі майора (3, с. 9); 2) спеціальні модальні частки (так, ну, ні, ага, точно): Так, так, точно 3 Мінська (3, с. 10). У цьому реченні модальні частки так, точно виражають згоду 3 висловленим та служать засобом підсилення ствердження; 3) вигуки (ой! ax! бa!) - виступають у ролі реченнявідповіді з модальним значенням стверджувальності : Ой, скільки там гармат за горою, - не годен перерахувати (3, с. 14); 4) спеціальна інтонація (здивування, сумніву, впевненості): Снаряди їх не беруть! (3, с. 15). Кожну лексему цього речення мовець вимовляс 3 підкресленням, посилюючи голос, з інтонацією впевненості; 5) порядок слів (заперечення, ствердження, іронія): Він буде з тобою розмовляти. Буде він з тобою розмовляти. Перше речення передає стверджувальне значення, а друге - іронічне.

Отже, стверджувальними й заперечними реченнями зазвичай констатують наявність чи відсутність реальних / ірреальних явищ або виражають застереження щодо їх можливості / неможливості. Це речення функційно висхідного типу. Дієслово-присудок у розповідних двоскладних реченнях або дієслівний головний член односкладного речення виражається різночасовими формами дійсного способу або дієсловом у формі наказового чи умовного способу.

2) Відносна закінченість змісту розповідного речення як одна 3 його обов'язкових ознак. Думка, яку виражає речення, ніколи не сприймається як абсолютно завершена, бо теоретично й практично це означало б, що зміст речення та його граматична структура представлені в якому-небудь остаточному варіанті, вияві. Навіть розповідне речення на зразок Шелестить осика тонким листям не можна вважати абсолютно завершеним ні за змістом, ні за граматичною будовою, бо його можна представити в багатьох варіантах, утворюваних додаванням до цього речення різних лексем: Шелестить (наша) осика (сьогодні) тонким листям.

3) Логічна сутність розповідного речення. Розповідні речення мовець використовує, щоб констатувати той чи той факт реальної дійсності. Наприклад: Широкою долиною між двома рядками розложистих гір тихо тече по Васильківщині невеличка річка Раставиия $(10$, c. 22$)$. Їх зазвичай розглядають як мовні форми вираження судження. 
Судження завжди виражається реченнями й буває стверджувальним або заперечним, наприклад: Саме тоді пішла дорога з Києва недалечко од Семигор (10, с. 28 ); Не тиха задуманість, не поетична мрія про історичну минувшість, про давнину повіває своӥм крилом над могилою Шевченка, ні (10, с. 32). П. С. Дудик зазначає, що кожне судження $є$ трикомпонентним та виокремлює суб'єкт судження (те, про що розповідають або заперечують), предикат судження (те, що саме в ньому стверджують чи заперечують про суб'єкт судження) і зв'язки («є», «не є») [5, с. 70]. Наприклад, у реченні Минав рік, підмет рік відповідає суб'єктові судження, а присудок минав - предикатові судження, а зв'язку виражено флексією дієслова-присудка минулого часу.

Судження - це основна форма мислення, думки, якою що-небудь стверджують (стверджувальні судження) або заперечують (заперечні судження) щодо осіб, предметів, явищ, природи, різноманітних виявів життя, передовсім людини в ньому [5, с. 69].

У формальній (класичній) логіці, а також у граматиці, що будує свої трактати на положеннях формально-логічної теорії, вивчають єдину форму мислення - судження й відповідний йому тип речень - розповідні [6]. Розповідні речення називають ще висловлюваннями. Висловлювання - це назва множини розповідних речень, смислом яких є судження, а значенням - такі логічні об'єкти, як «істинність» і «хибність». Оскільки предметом нашої уваги є розповідні речення, поза межами спеціального аналізу терміни «висловлювання» і «речення» ототожнюємо. Під час аналізу розповідне речення розглядають як послідовність знаків, що відповідає вимогам правил цієї мови (це синтаксична категорія) і яка своїм змістом має висловлювання (це семантична категорія). Оскільки висловлювання як семантична категорія фіксує в собі мовні відрізки, що виражають судження, iї визначають як основну. Це зумовлено тим, що дослідження природи судження дає ключ до розуміння структури поняття як форми мислення й розкриває механізми функціонування понять і суджень у структурі умовиводу.

3 усієї множини речень (розповідних, запитальних, окличних) логіку, насамперед, цікавлять розповідні речення. Інтерес логіки до розповідних речень зумовлений тим, що вони є носіями такої логічної форми, як судження [7].

4) Граматична організованість розповідних речень, які підлягають усемовним закономірностям у властивому їм синтаксичному оформленні. 


\section{СТРУКТУРА I СЕМАНТИКА МОВНИХ ОДИНИЦЬ}

Зв'язок між ствердженням та розповідністю можна простежити і в межах граматичної теорії, а саме в перевазі нейтрального статусу позитивних форм розповідного речення щодо негативних. Структурний синтаксис, трансформаційна граматика як базову модель розглядають стверджувальне розповідне речення [6, с. 10].

Стверджувальне речення сприймається як вихідна, семантично базисна модель розповідного речення. Стверджувальні розповідні (наративні) двоскладні речення повідомляють про те, що відбувається в світі об'єктивної дійсності й відображають стандартну модель цього типу речень.

Г. Пауль зазначає, що розповідні речення - це «нормальний» тип речень. Мовознавець наголошує на тому, що в розповідних реченнях семантика ствердження / заперечення постає в «чистому» вигляді, на неї не впливає особливий семантичний фон, що створюється під час функціонування категорії ствердження / заперечення в умовах питальної чи спонукальної семантики. Під час аналізу значень ствердження / заперечення, що реалізуються в межах класу не розповідних речень, найосновнішим $є$ з'ясування специфіки вияву цих відносин у семантичних умовах питальності чи спонукальності.

Розповідні речення $є$ зручним матеріалом для спостереження мовного ствердження / заперечення в трьох значеннях, характерних для сучасних підходів до мови, - у площині граматики, семантики і прагматики цих відносин [11, с. 126].

5) Інтоначійна завершеність розповідних речень. Важливу роль у формуванні стверджувального чи заперечного значення відіграє інтонація. Інтонація $є$ одним із засобів передачі об'єктивносуб'єктивних відношень у мовленні. Характеристика інтонаційної завершеності розповідних речень чітко постає на фоні чотирьох типів розповідних речень, а саме: власне розповідних, речень-повідомлень, речень-пояснень, речень-заяв.

Власне розповідні речення в процесі комунікації слугують для констатації, ствердження того чи того факту реальної дійсності, хоч звернення до співрозмовника не є прямим, а має опосередкований характер. Наприклад: Шлях у місто мені вже знайомий був - кілька раз з дядьком та дядиною їздили у ярмарок, - нічого було питати дороги (8, с. 20); Пішла Катря в село до дядька та дядини, та недовго була в родичів $(8$, с. 225$)$. Реакція співрозмовника відносно пасивна на речення цього типу і не потребує негайного втручання в акт комунікації. Iз 
прикладів видно, що власне розповідні речення використовують для констатації певного факту або серії фактів 3 метою створення його загального образу. Оскільки ці реченняє обов'язковими складниками суцільного контексту, інтонаційне оформлення повністю визначає їх функцією у загальній сукупності сприяти створенню в слухача певного образу предмета висловлення. В. Бузинська зазначає, що підвищення тону початку власне розповідного речення вказує на продовження незавершеної думки попередньої фрази, а вимова кінцівки фрази 3 піднесенням тону уособлює констатацію, сигнал про те, що комунікація завершена, наступне речення продовжуватиме подальше витлумачення думки [1, с. 72].

Речення-повідомлення $є$ безпосереднім зверненням до співрозмовника 3 метою інформації учасників комунікативного акту про той чи той предмет, явище чи дію, що становить інтерес для співрозмовника. Наприклад: Одного разу попрохав він у мене карбования (8, с. 32); Уже, - кажу, - краще не буде, як і так $\epsilon$ (8, с. 34). Зауважимо, що речення-повідомлення відрізняється від власне розповідного речення конкретнішою констатацією (ствердженням) факту.

Речення-пояснення $\epsilon$ комунікативним видом розповіді, характерним як для діалогічного, так і для монологічного мовлення. Функціонування речення-пояснення можливе лише у зв'язку 3 попереднім висловлюванням, пояснювати яке воно покликане: $\mathrm{He}$ тільки Мотрю, а й ї̈ матір стару стали цуратися люди. Саме те місие, де вони жили, зробилося якимсь страшним, - стали його оббігати (8, с. 254); Як я до тебе йшла - як ластівочка щебетала, назад повертаюся - вороном крячу (8, с. 39). Отже, пояснюючи, мовець акцентує увагу слухача на одному певному моменті.

Речення-заяви за своїм комунікативним спрямуванням аналогічні реченням-повідомленням. Вони звернені своїм змістом до безпосереднього конкретного слухача й покликані не просто інформувати співрозмовника про той чи той факт, дію чи явище, а й викликати відповідну реакцію слухача. За своїм смисловим змістом речення-заяви, констатуючи, конкретизуючи певні думки, являють собою певний сигнал, що спонукає до дії. Наприклад: То скажіть же ви їй, моя матінко, хай вона додому йде, до дядька, до дядини вертається (8, с. 38); Коли б ти, бісова Шестірня, хоч раз занедужала, то, може б, поняла віри (8, с.100).

Потрібно зазначити, що для розповідних речень у контексті ๑) О. В. Гурко, 2014. 
відношення ствердження / заперечення дуже важлива типова для них розповідна інтонація, яка має замкнену структуру: початок, розгортання, завершення. Тон підвищується на одному із членів речення, який внаслідок цього логічно, семантично виділяється, позначаючи найосновніше в повідомленні, і знижується наприкінці речення.

Отже, кожну лексему в розповідному (так само як і в питальному, спонукальному) реченні виділяють логічним наголосом, яким акцентують увагу мовців на тому слові в реченні, яке семантично й стилістично найважливіше за кожної окремої мовленнєвої ситуації. Унаслідок цього витворюють різні функційно-стилістичні варіанти речень, пор.: Козаки брали участь у багатьох походах на турків $(3$, c. 234$)$ : унаслідок почергового логічного виділення в цьому реченні кожного 3 повнозначних слів утворюють його різні стилістичні варіанти: Козаки (а не хтось інший) брали участь... і т. ін.

6) Комунікативність розповідних речень. Це ознака в категорії речення будь-якої граматичної будови й лексичного наповнення речень розповідних і не розповідних - $є$ для них завершальною, у ній зреалізовується комунікативність речення, тобто те, задля осягнення чого й формують речення, у цьому випадку - розповідні.

Значення, що виражаються в модусі й виявляються в зміні речення, складають граматичні (або комунікативні, синтаксичні, модусні) категорії речення. Ці категорії відображають єдність певного значення (наприклад, питання, заперечення, спонукання, виділення тощо) і певної форми [4, с. 145].

М. В. Мірченко зазначає, що грамему підкатегорії розповідності характеризує широкий спектр компонентів структури речення. Видається правомірною констатація того, що спеціальних граматичних показників під категорії розповідності немає, бо дійсний спосіб дієслова-присудка можливий і в інших функційних типах речень, хоч і переважає в розповідних. Мовознавець наголошує на тому, що форма розповідності властива передусім реченням, які констатують факт та постають як наслідок інформативного осмислення, створюваного взаємодією граматичної семантики форми та лексичної семантики наповнювача цієї формули. Стверджувальна розповідна семантика найповніше представлена односкладними (називними і безособовими) реченнями, які стверджують чи заперечують буття (екзистенційність) факту, явища, події, стану природи чи людини тощо [9, с. 87]. Наприклад: На захід! На захід! (3, с. 5); Степи... (3, с. 8); I ні душі 
навколо (8, с. 56). Утім ця сама семантика, що констатує факт, як зазначає М. Мірченко, властива й для інших структурних різновидів не односкладних та односкладних і складних речень [9, с. 87]: Сироти - цее діти (3, с. 6); У селі теж залягла тиша, подвір'я позаростали бур'янами, мешканців звідси було евакуйовано в тил (3, с. 8).

Отже, використовуючи тип розповідних речень як базову модель для вивчення значення ствердження / заперечення, ми з'ясували, що клас повідомлень, або стверджень, утворюють дуже різноманітні як у структурному, так i в семантичному планах висловлювання. До розповідних речень уналежнюють висловлювання, які оформляють різні види модальних суджень (судження повинності, можливості, потреби), імовірні судження, судження якості, емотивні та аксіологічні висловлювання, 3 властивими кожному 3 них особливостями сфери смислів, узагальнених в поняттях «ствердження» i «заперечення». Розповідні речення зазвичай повідомляють про яку-небудь подію, констатують позитивний або негативний факт, чи, наприклад, підтверджують / спростовують факт наявності / відсутності чого-небудь у дійсності, чи стверджують що-небудь як істинне або заперечують як помилкове. Перспективою подальшого дослідження можна вважати аналіз питальних речень у контексті відношень ствердження / заперечення.

\section{Література}

1. Бузинська В. Інтонаційні засоби вираження мовної модальності / В. Бузинська // Науковий вісник Чернівецького ун-ту : зб. наук. праць. Слов'янська філологія. Чернівці : ЧДУ, 1996.- Вип. 9. - С. 71-75.

2. Валимова Г. В. Функциональные типы предложений в современном русском языке / Г. В. Валимова. - Ростов н/Д. : Изд-во Рост, ун-та, 1967. - 331 с.

3. Гончар О. Твори в двох томах / О. Гончар. - Т. 2. - К. : Вид-во художньої літератури «Дніпро», 1966. - $750 \mathrm{c}$.

4. Горпинич В. О. Українська морфологія / В. О. Горпинич. - К. : Видавничий центр «Академія», 2004. $-336 \mathrm{c}$.

5. Дудик П. С. Синтаксис української мови / П. С. Дудик, Л. В. Прокопчук. - К. : Видавничий центр «Академія», 2010. - 384 с.

6. Жаровська О. Питальне речення: деякі питання теорії / О. Жаровська // Наукові записки. Серія : Філологія : зб. наук. праць, 2008. - Вип. 10. - Т. 1. - С. 176-180.

7. Ивин А. А. Словарь по логике / А. А. Ивин, А. Л. Никифоров. - М. : Гуманит. изд. центр ВЛАДОС, 1997. - 384 с.

8. Мирний Панас. Твори в двох томах / Панас Мирний. - Т. 1. - К. : Видавництво художньої літератури «Дніпро», 1985. - 552 с.

9. Мірченко М. В. Структура синтаксичних категорій / М. В. Мірченко. - Луцьк. : Редакційно-видавничий відділ Волинського державного університету імені Лесі С О. В. Гурко, 2014. 
Українки «Вежа», 2001. - 340 с.

10. Нечуй-Левицький I. С. Твори в трьох томах / I. С. Нечуй-Левицький. - Т. 3. К. : Видавництво художньої літератури «Дніпро», 1988. - 643 с.

11. Пауль Г. Принципы истории языка / Г. Пауль. - М. : Изд-во иностр. лит-ры, 1960. $-500 \mathrm{c}$.

12. Плющ Н. П. Інтонаційні засоби диференціації комунікативних різновидів розповіді в українському діалогічному мовленні / Н. П. Плющ // Мовознавчі студії. К., 1976. - С. 80-84.

13. Українська мова. Енциклопедія / [редкол. В. М. Русанівський, О. О. Тараненко (співголови), М. П. Зяблюк та ін.]. - [3-є вид. зі змінами і доп.]. - К. : Вид-во «Укр. енциклопедія» ім. М. П. Бажана, 2007. - 856 с.

Стаття надійшла до редакиії 11.09.2014 p. 